http://dx.doi.org/10.7197/1305-0028.94406

\title{
Cerebral sinus venous thrombosis in puerperium: Review of the literature in the light of two cases
}

\section{Lohusalıkta serebral sinüs ven trombozu: İki olgu ışığında literatürün gözden geçirilmesi}

\author{
*Yıldız Değirmenci ${ }^{1}$, Hulusi Keçeci ${ }^{1}$, İlknur Suadiye Şeker ${ }^{2}$ \\ ${ }^{1}$ Department of Neurology, Düzce University School of Medicine \\ ${ }^{2}$ Department of Anesthesiology and Reanimation, Düzce University School of Medicine \\ Corresponding author: Dr. Yıldız Değirmenci, Nöroloji Anabilim Dalı, Düzce Üniversitesi Tıp Fakültesi, \\ TR-81620, Düzce \\ E-mail: ydegir@gmail.com \\ Received/Accepted: February 12, 2015/March 26, 2015 \\ Conflicts of interest: The authors stated that they have no conflicts of interest.
}

\section{SUMMARY}

Cerebral venous sinus thrombosis (CSVT) is the presence of thrombosis in the dural vein, resulting with a variety of symptoms including seizure, loss of consciousness, focal neurological deficits, stroke and intracranial hypertension. Headache is the most common symptom of intracranial hypertension with or without vision loss, cranial nerve palsies. Since CSVT is more common in women regarding to the predisposing risk factors such as sex hormones, pregnancy, puerperium, which are unique to women, we reported these cases in order to emphasize the importance of considering this life-threatening, neurological emergency in women with headache complaint.

Keywords: Sinus venous thrombosis, headache, puerperium

\section{ÖZET}

Serebral sinus ven trombozu (SSVT) nöbet, bilinç kaybı, fokal nörolojik defisitler, inme ve intrakraniyal hipertansiyonu içeren farklı semptomlarla sonuçlanan, dural venlerdeki tromboz varlığıdır. Görme kaybı, kraniyal sinir felçleri eşlik etsin veya etmesin, baş ağrısı en sık intrakraniyal hipertansiyon semptomudur. SSVT, cinsiyet hormonları, gebelik ve lohusalık gibi özel predispozan risk faktörleri nedeniyle kadınlarda daha sık görüldüğünden, olgular baş ağrısı şikayeti olan kadınlarda yaşamı tehdit eden bu acil nörolojik tablonun önemini vurgulamak amaciyla sunuldu.

Anahtar sözcükler: Sinüs ven trombozu, baş ağrısı, lohusalık

\section{INTRODUCTION}

Cerebral venous sinus thrombosis (CVST) is the presence of thrombosis in the dural vein, which occurs when a blood clot forms in the brain's venous sinus that prevents blood from draining out of the brain 1. It is a rare cause of cerebral infarction, accounting for only about $0.5 \%$ of patients with stroke, especially effecting individuals younger than the age of $50^{2}$. In addition to stroke, it may occur with a variety of symptoms including ischemic and/or hemorrhagic infarcts, seizures, altered consciousness, and headaches.
The underlying mechanisms of these different spectrums of symptoms are based on two major mechanisms including thrombosis of cerebral veins causes' localized edema of the brain and venous infarction, and the thrombosis of the major sinuses leads to intracranial hypertension as a result of increased venous pressure and impaired absorption of cerebrospinal fluid ${ }^{3,4}$.

Since it has a female dominance of $75 \%$, regarding to the sex-specific factors that occur in women including oral contraceptives, hormone replacement therapies, pregnancy, and lactation leading to throm- 
bosis $^{1,2}$, we here reported three cases of CSVT in the lactation period.

\section{CASE REPORT ${ }^{\mathbf{1}}$}

A 30 year old right-handed woman presented to our outpatient neurology clinic with a new onset of diffuse, severe, sharp, stabling headaches. She had a history of delivery with spinal anesthesia 10 days ago. There was no nausea, vomiting, photophobia, and/or phonophobia. She had preeclampsia during pregnancy, intrauterine fetal death in the 28th week of her prior pregnancy. There was no drug use, and no medical illness. Her family history revealed death due to leukemia and systemic lupus erythematosus in her sisters. On presentation, her vital parameters were normal. She was afebrile. She had painful eye movements, accompanying bilateral, diffuse, pulsatile, and gradually increasing severe headaches with a visual analog scale (VAS) score of 9. Neurological examination of the patient was normal other than bilateral papilledema. Laboratory investigations revealed an increased erythrocyte sedimentation rate (ESR) of 95 millimeters per hour. Total blood count, full biochemical screen, coagulopathy and thrombophilia panel, serum homocysteine levels, and markers of vasculitis including antiphospolipid antibodies were normal. Brain magnetic resonance imaging (MRI) of the patient demonstrated an increased attenuation of the left transverse sinus, suggestive of thrombosis (Figure 1). Magnetic resonance venography (MRV) revealed a total occlusion in the left transvers sinus and a partial occlusion in the distal segment of the superior sagittal sinus (Figure 2a-b). Subcutaneous (SC) low molecular weight heparin (LMWH) of $0.8 \mathrm{cc}$ twice daily, oral acetazolamide $250 \mathrm{mg}$ four times a day was administered to the patient. On the third day of her hospitalization, horizontal lateral gaze paralysis in the left eye and diplopia appeared suggesting elevated intracranial pressure. Thus, an osmotic diuretic agent was added to the treatment. Headaches of the patient begun to resolve following anti edema treatment. VAS score decreased to 5, with more frequent headache-free periods. There was no pain during the eye movements. Lateral gaze palsy and diplopia disappeared at the fifth day. After one week, she had no headaches, and funduscopic examination with eye movements returned to normal. The LMWH was switched to adjusted-dose warfarin daily after delivery with a targeted international normalized ratio (INR) of 2 to 3. Control MRV of the patient revealed a partial recanalization.

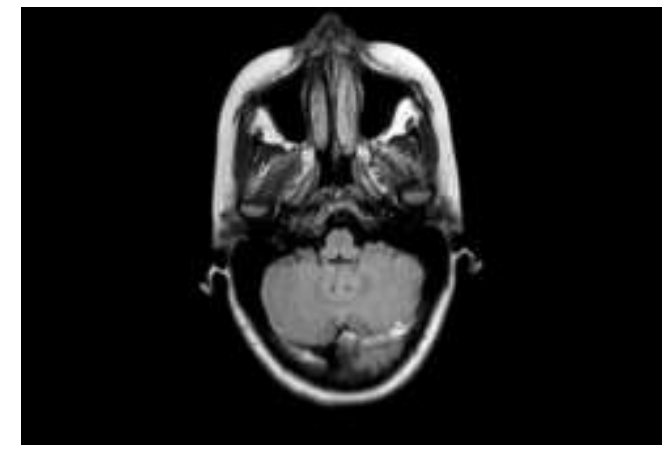

Figure 1: Kraniyal MRI-Axial FLAIR image. Hyperintense signal in the left transvers sinus.

\section{CASE REPORT ${ }^{2}$}

A 29 year old right-handed woman presented to our outpatient neurology clinic with a new onset of severe, pulsatile headaches around the entire head following postoperative seventh day of caesarean section with spinal anesthesia. VAS score of her headaches were ${ }^{8}$. She had vertigo, photophobia accompanying headaches. She had a medical history of preeclampsia during pregnancy. There was no drug use, and no medical illness. She had no fever. Her initial neurological examination revealed stabilized vital parameters. Pathological findings of her neurological examination were a mild conjugated lateral gaze paralysis in the left with horizontal nystagmus. Routine laboratory findings and coagulopathy and thrombophilia panel, serum homocysteine levels, and markers of vasculitis were in normal ranges except elevated ESR level of 94 millimeters/hour. MRV revealed a partial occlusion in the left transvers sinus (Figure-3). After the administration of subcutaneous LMWH of $0.8 \mathrm{cc}$ twice daily, oral acetazolamide 250 $\mathrm{mg}$ four times to the patient, headaches and lateral gaze paralysis begun to resolve gradually. The LMWH was switched to adjusted-dose warfarin daily after delivery with a targeted INR of 2 to 3 after one week. 

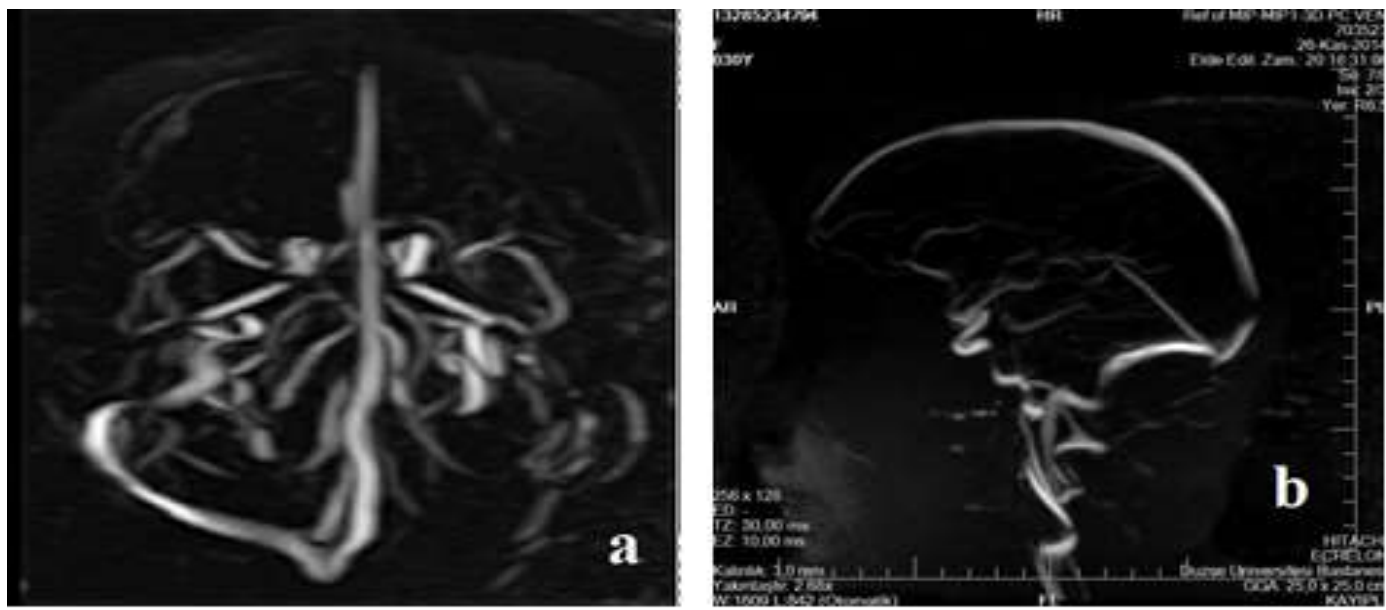

Figure 2: Brain MRV. 2a: Total occlusion in the left transvers sinus. 2b: Partial occlusion in the superior sagittal sinus.

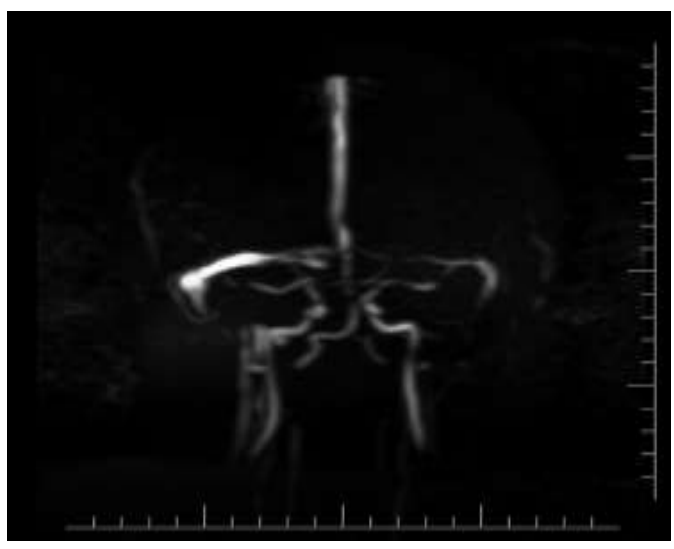

Figure 3. Brain MRV: Partial occlusion in the left transvers sinus.

\section{DISCUSSION}

We reported two young women in the postpartum period, who presented with headache complaint and were diagnosed as CSVT. Since CSVT has a variety of clinical presentations, headache is the most common symptom, affecting approximately $90 \%$ of the patients with CSVT $^{2}$. It is one of the main features of isolated intracranial hypertension, in which patients may present with diplopia, visual impairment, decreased level of consciousness, or sixth nerve palsy, as well as headache. However there is a wide range of symptomatology including seizures, encephalopathy, focal neurological deficits ${ }^{4,5}$.

As we also demonstrated in our cases, the most commonly affected venous sinuses are superior sagittal sinus, followed by the transvers sinus with the frequencies of $62 \%$, and $41 \%$, respectively ${ }^{6,7}$. In addition to chronic triggers including hereditary or acquired thrombophilias, transient triggers or predisposing risk factors for thrombosis are ear/sinus/mouth/face infections, exposure to drugs as oral contraceptives, steroids, head trauma, or procedures as lumbar puncture, jugular catheter placement, as well as pregnancy, puerperium ${ }^{4,5,8}$. Since female sex factors are one of the major predisposing factors triggering the underlying mechanism of thrombosis, female gender is one of the major risk factors with a frequency rate of 3 to 1 , when compared with men ${ }^{9}$. Suggesting our cases that have no other identifiable risk factor for thrombosis other than female gender and puerperium, previous reports demonstrated a $65 \%$ of identifiable causes of CSVT in women are related to pregnancy, puerperium, oral contraceptive use, or hormonal therapies which are unique to women ${ }^{5,9}$.

Since a clinical suspicion of CSVT is the first step of diagnosis, further neuroimaging techniques should be used to confirm CSVT including computerized tomography venogram, brain MRI, MRV, conventional angiogram. However, the suggested investigation methods according to the EFNS and AHA guidelines are MRI and MRV as the preferred brain images ${ }^{7,10}$.

As reported in the diagnosis and management guidelines of CSVT, acute management of CSVT includes strategies aiming to recanalize the thrombosed sinus or sinuses, and the prevention of medical complications with the treatment of underlying causes ${ }^{11}$. Anticoagulation is the standard treatment which prevents thrombus 
growth, facilitates recanalization, prevents other thrombotic events such as deep venous thrombosis and pulmonary embolism, and lowers the risk of mortality ${ }^{11,12}$. Thus we began anticoagulation with LMWH which was switched to oral anticoagulant in the maintenance period, as we confirmed the diagnosis of our cases with MRV. However, different endovascular approaches including thrombolysis, mechanical thrombectomy, can also be considered in patients with progressive neurologic deterioration despite intensive medical treatment including anticoagulation ${ }^{12}$. In order to treat complications of CSVT, such as seizures, intracranial hypertension presenting with headache, visual loss, and or deterioration of consciousness, symptomatic therapy must be added to anticoagulation including antiepileptic agents, osmotic diuretics, carbonic anhydrase inhibitors, serial lumber punctures, and optic nerve fenestrations ${ }^{4,12}$.

In conclusion; CSVT is a clinical entity with various symptoms which may present with mild to severe headaches, visual loss, seizures, loss of consciousness, and/or different combinations of these symptoms. Since it is one of the life-threatening neurological emergencies, a detailed history and a careful neurological examination must be made not to underestimate the disease. On this aspect, we reported these two young women in order to emphasize the importance of detailed evaluation of headaches, especially in the presence of risk factors for thrombosis such as pregnancy, puerperium, oral contraceptive use, etc. CSVT must be kept in mind, especially in young women of reproductive age. Because without clinical suspicion and further neuroimaging investigations, the headaches of different severities may easily be misdiagnosed as tension-type headache or migraine, leading to neurological deficits and even death.

\section{REFERENCES}

1. Ferro JM, Canhao P, Stam J, Bousser MG, Barinagarrementeria F. ISCVT Investigators. Prognosis of cerebral vein and dural sinus thrombosis: Results of the international study on cerebral vein.
Stroke 2004; 35: 664-70.

2. Bousser MG, Ferro JM. Cerebral venous thrombosis: An update. Lancet Neurol 2007; 6: 162-70.

3. Stam J. Thrombosis of the cerebral veins and sinuses. N Engl $\mathrm{J}$ Med 2005; 352: 1791-8.

4. Bushnell C, Saposnik G. Evaluation and management of cerebral venous thrombosis. Continuum 2014; 20: 335-51.

5. Ferro JM, Canhão P. Cerebral venous sinus thrombosis: Update on diagnosis and management. Curr Cardiol Rep 2014; 16: 523.

6. Wasay M, Azeemuddin M. Neuroimaging of cerebral venous thrombosis. J Neuroimaging 2005; 15: 118-28.

7. Ganeshan D1, Narlawar R, McCann C, Jones HL, Curtis J. Cerebral venous thrombosis-A pictorial review. Eur J Radiol 2010; 74: 110-6.

8. Girot $\mathrm{M}$, Ferro JM, Canhão $\mathrm{P}$, Stam J, Bousser MG, Barinagarrementeria F, Leys D. Predictors of outcome in patients with cerebral venous thrombosis and intracerebral hemorrhage. Stroke 2007; 38: 337-42.

9. Coutinho JM, Ferro JM, Canhão $P$, Barinagarrementeria $\mathrm{F}$, Cantú $\mathrm{C}$, Bousser MG, Stam J. Cerebral venous and sinus thrombosis in women. Stroke 2009; 40: 2356-61.

10. Leach JL, Fortuna RB, Jones BV, Gaskill-Shipley MF. Imaging of cerebral venous thrombosis: Current techniques, spectrum of findings, and diagnostic pitfalls. Radiographics 2006; 26: 19-41.

11. Coutinho JM, Middeldorp S, Stam $\mathrm{J}$. Advances in the treatment of cerebral venous thrombosis. Curr Treat Options Neurol 2014; 16: 299.

12. Al-Hashel JY, John JK, Vembu P. Venous thrombosis of the brain. Retrospective review of 110 patients in Kuwait. Neurosciences (Riyadh) 2014; 19: 111-7. 